を並べて同一視距離で視る事は方法に適したものとは 云いがたい,そこで $60 \mathrm{~m} / \mathrm{m}$ 判の観察倍率の適度を検討し て見ょう。

さきに鮮鋭度試験体を撮影して置いたフィルムに就 いて検討して見た結果次の様になった。 その判定方法 は主観的観察法に依る事とし三四人で観察して正確に 近くする様にした。判定用具は顕微鏡の㸡測計を用い 像を50倍に拡大して判読しそれを平均した。その時の 濃度差は大体であるが1.3〜0.3の間を示していた。こ れにより

直接フィルムのボケは $0.06 \frac{m}{m}$

間接フィルムのボケは $0.2^{\mathrm{m} / \mathrm{m}}$

のボケが主観的に求める事が出来た。

これを明視の距離で観祭するには, 間接フィルムは 2.17 倍に拡大するのが適当と思うので $0.434 \frac{m}{m}$ のボケ となる。 その視角は 6 分近くなる, 従って直接フィル ムと比較すると6 倍の視解を示守事になる。従っで洶
部間接撮影にあたり焦点螢光板距離に応じて被写体の 各部の影像は更にボケを伴って来る訳でてれ以上の拡 大を望む事は観察上折传良好な写真を得てもその效率 は低下してくる，従っててれを市販の $35 \frac{\mathrm{m} / \mathrm{m}}{\mathrm{m}}$ 判例用観察 箱で観察する場合はその細部像が照明の影響とあいま つてボケに蔽われて来る事を考えねばならない。この 様に考えて来ると次の結諭を得た。

結論

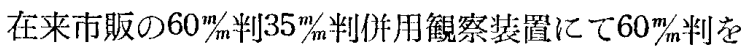
钼察する事は好ましい事ではない。光学的にも2 倍以 内が適当だろうと考えられる。五吾々技師好次式に依 り拡大鏡の倍率を沃定して虫服鏡の焦点距離を求め, かくして拡大鏡を選定し観察者である医師に引渡す位 にすべきではないかと考える。文照明も然りである。 中ぬが权の焦点距離 $=\frac{250}{\text { 引伸倍率 }-1}$

\title{
エックス線量と湿度の電気絕綠材料に及ぼす劣化に就て
}

\author{
国立松戸療養所 \\ （指導 医務課長 神野友次）喜 多 義 雄 (論文受付 昭和29年 9 月 1 日)
}

本論文の要旨は昭和 29 年 4 月 3 日岡山に於ける本会第10回総会に於て演説発表した。

\section{ON WORSENING OF INSULATORS RESULTING FROM HUMIDITY AND X-RAY EXPOSURE.}

\author{
By Yoshio Kita \\ The National Sanatorium at Matsudo. \\ (Under the Guidance of Medical Superintendent, Tomoji Kamino)
}

(Article received : September 1, 1954)

The outline of this article was publised at the 10th General Meeting of this Association in Okayama April 3, 1953.

\section{Summary}

The (ever-) increasing of the utilization of electric energies has resently led to surprising betterment of insulators in general use as same as those of the X-ray apparatus. About the worsening of insulators, installed to the X-ray apparatus, which may be influenced by humidity and X-ray exposure, however, it has not been studied well.

It has been made clear that some kind of insulators have been deteriorated (by) the exposure of the sunlight and ultra-violet rays. But it has not been seemed clear that whether the insulators, particularly the organic iones inthem, have been influenced or not by the X-ray exposure. 
I chose seven sorts of insulation materials in common use and after exposing them to X-ray untill required extent, I placed them under different grades of humidity and measured the surface leakage current.

I expect that the experimental results will institute the considerable problem on the insulation materials used in X-ray apparatus.

\section{緒言}

近時電気絶縁材料の発達は最近の電気エネルギーの 高度の利用につれて，実に素晴しいものがある．X線 装置に使用されている絶縁材料に於ても亦同様であ る. しかし其の性質上湿度及び $\mathrm{X}$ 線の暴射に依る絶緑 物の少化を考虑され㸚ばならない䈏である。

絶縁材料の或る種類の物は, 日光, 紫外線, 等に依 り少化されるが、未だX線照射により絶緑村料, 殊に 固体有機絶緑材料が，絶緑性に変化を及ぼすか否か不 明の様である。私は普通使用される材料中 7 種類虑選 び, 実験的にX線を曝射し, 一応目的線量に達した後 湿度を変化させて，其の表面漏波電流を测定した。本
实験はX線装置に使用されている電気絶縁材料に対し 常に教虑される可き問題乞考えるので此所に報告する。

第 I表 実 験 材 料

\begin{tabular}{|c|c|c|}
\hline 品 & & 製作会社名 \\
\hline ב & 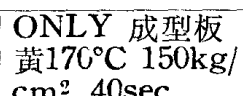 & 富士化成 \\
\hline フェノールシン & 積層板 $0.77^{m} / m$ & $\begin{array}{l}\text { 日本化工材工業 } \\
\text { (狍崎) }\end{array}$ \\
\hline ビ =ラール & 緑 & 文化電気工業 \\
\hline$フ \pm ノ-ル$ & 成型品(黒) & 理 研 合成 \\
\hline ב リ & 成型品(赤) & " \\
\hline$\times \quad \bar{z}$ & $100 \%$ 成型品(白) & " \\
\hline エボナイト & & 不 \\
\hline
\end{tabular}

\section{第2表 レントゲン照射線量表}

\begin{tabular}{|c|c|c|c|c|c|c|c|c|}
\hline 数 & $\begin{array}{c}\text { 湿 }{ }^{\%} \text { 度 }^{\circ} \\
\mathrm{R} . \mathrm{H} .\end{array}$ & $\begin{array}{c}\text { 趾 離 } \\
\text { 粕 }\end{array}$ & $\begin{array}{c}\text { 管 電 圧 } \\
\mathrm{kV}\end{array}$ & $\begin{array}{c}\text { 管電流 } \\
\text { MA }\end{array}$ & $\begin{array}{c}\text { 照射㬨間 } \\
\text { 分 }\end{array}$ & 線 量 & $\begin{array}{ll}\text { 線 量 } \\
\mathrm{r}\end{array}$ & 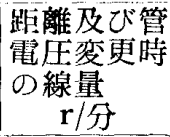 \\
\hline 第 1 日 & & 50 & 60 & 3 & 30 & 112.5 & 112.5 & 3.75 \\
\hline 2 日 & 85 & 50 & 60 & 3 & 41 & 153.75 & 266.25 & 3.75 \\
\hline 3 日 & 66 & 65 & 60 & 3 & 30 & 112.5 & 378.75 & 2.14 \\
\hline 4 日 & 69 & 65 & 60 & 3 & 70 & 149.8 & 528.55 & 2.14 \\
\hline 5 日 & 66 & 65 & 60 & 3 & 20 & 42.8 & 571.35 & 2.14 \\
\hline 6 日 & 78 & 65 & 60 & 3 & 15 & 32.1 & 603.45 & 2.14 \\
\hline 7 日 & 65 & 65 & 65 & 3 & 67 & 180.9 & 784.35 & 2.7 \\
\hline 8 日 & 70 & 65 & 65 & 3 & 22 & 59.4 & 843.75 & 2.7 \\
\hline 9 日 & 65 & 65 & 65 & 3 & 75 & 202.5 & 1046.25 & 2.7 \\
\hline $10 日$ & 62 & 65 & 65 & 3 & 45 & 121.5 & 1167.75 & 2.7 \\
\hline $11 日$ & 64 & 65 & 65 & 3 & 34 & 91.8 & 1259.55 & 2.7 \\
\hline 12日 & 57 & 65 & 65 & 3 & 50 & 135 & 1394.55 & 2.7 \\
\hline 13日 & 63 & 65 & 65 & 3 & 60 & 162 & 1556.6 & 2.7 \\
\hline 14日 & 74 & 65 & 65 & 3 & 80 & 216 & 1772.6 & 2.7 \\
\hline 15日 & 72 & 65 & 65 & 3 & 20 & 54 & 1826.6 & 2.7 \\
\hline 16日 & 70 & 65 & 65 & 3 & 35 & 94.5 & 1921.1 & 2.7 \\
\hline 17日 & & 65 & 65 & 3 & 40 & 108 & 2029.1 & 2.7 \\
\hline 18日 & 64 & 65 & 65 & 3 & 75 & 202.5 & 2231.6 & 2.7 \\
\hline 19日 & 68 & 65 & 65 & 3 & 55 & 148.5 & 2380.1 & 2.7 \\
\hline 20日 & 69 & 65 & 65 & 3 & 90 & 243 & 2623.1 & 2.7 \\
\hline 21日 & 64 & 65 & 65 & 3 & 50 & 135 & 2758.1 & 2.7 \\
\hline 22日 & 70 & 65 & 65 & 3 & 50 & 135 & 2893.1 & 2.7 \\
\hline 23日 & 64 & 65 & 65 & 3 & 10 & 27 & 2920.1 & 2.7 \\
\hline 24日 & 73 & 65 & 65 & 3 & 30 & 81 & 3001.1 & 2.7 \\
\hline
\end{tabular}




\section{実験材料及び方法}

本実験に使用の材料は第 1 表の如き 7 種類を選び， 第 2 表の如くX線を照射した，X線装置は後藤風雲堂 ツト，ヘリオポス䧐断用を使用した。線量の測定に科 研直読式ポケット線量計索使用し, 照射線量は一応 3000レントゲンとした。

各材料に第 3,4 表及び第 1 図の如くX線を曝射し, 材料を適当に切断した後, ベンジンにて丁窑に拭い垁 験槽の中に懸垂格納した，材料の画電極間に直流定電 圧 960 ボルトを供給し, 実験槽の湿度を変化させて材 料の表面を流れる表面漏洩電流を反照検流計により測 定した。 又湿度の測定には毛髮湿度計を使用した。

第 3 表フエノール

\begin{tabular}{|c|c|c|c|}
\hline \multicolumn{2}{|c|}{ エックス線末照射 } & \multicolumn{2}{|c|}{ エックス線照射 } \\
\hline 湿 $\%$ & 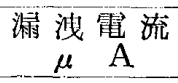 & $\begin{array}{c}\text { 漏溅電 流 } \\
\mu \mathrm{A}\end{array}$ & ${ }^{\text {温 }}{ }^{\circ}$ 度 \\
\hline 41.5 & 1.305 & 2.16 & 18 \\
\hline 53.5 & 1.46 & 2.50 & 18.5 \\
\hline 62 & 1.595 & 2.75 & 18.5 \\
\hline 74 & 1.96 & 3.20 & 18.5 \\
\hline 82.5 & 2.46 & 3.625 & 18.8 \\
\hline 82.5 & 2.59 & 3.77 & 18.7 \\
\hline 91.5 & 3.12 & 4.40 & 18.5 \\
\hline 97 & 4.63 & 5.62 & 18.5 \\
\hline
\end{tabular}

供給電圧直流 960 ボルト 電極間隔 $3.2 \mathrm{~mm}$

第 4 表 フェノールレジン

\begin{tabular}{|c|c|c|c|}
\hline \multicolumn{2}{|c|}{ エックス線末照射 } & \multicolumn{2}{|c|}{ エックス線照射 } \\
\hline 湿 ${ }_{\%}$ & 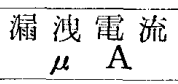 & $\begin{array}{c}\text { 渄洩電流 } \\
\mu \mathrm{A}\end{array}$ & ${ }^{\circ}{ }^{\circ}{ }^{\text {度 }}$ \\
\hline 42.5 & 0.0276 & 0.0252 & 18 \\
\hline 52 & 0.0315 & 0.03 & 18.5 \\
\hline 62 & 0.0366 & 0.041 & 18.5 \\
\hline 74 & 0.046 & 0.071 & 18.5 \\
\hline 78.5 & 0.0558 & 0.0987 & 18.8 \\
\hline 82.5 & 0.063 & 0.172 & 18.7 \\
\hline 90.5 & 0.0944 & 0.237 & 18.5 \\
\hline 97 & 0.216 & 0.575 & 18.5 \\
\hline
\end{tabular}

供給雷圧淔流 960 ボルト 筧極間隔 $3.25 \mathrm{~mm}$

\section{実験成績並に考察}

フェノール及びフェノールレジンは，石炭酸樹脂又 はベークライトと呼ばれている樹脂で現今広く使用さ れている．特性は第1図の如くで，X線を照射された
フエノール及び

フエノールV:゙ン

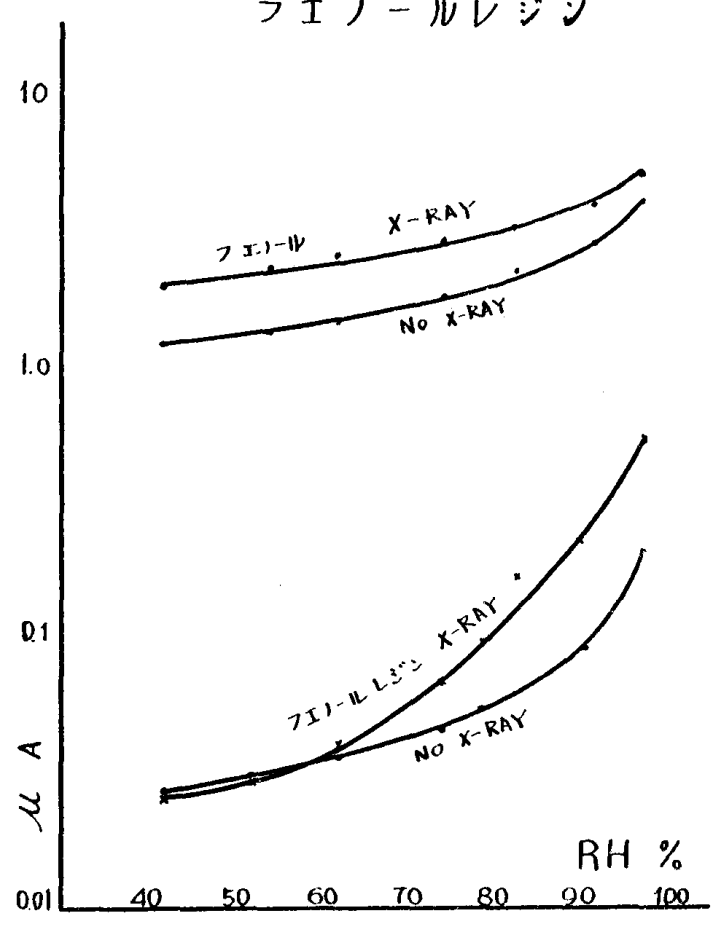

第 1 図

ものが未照射の材料よりも表面漏洩電流が増加してい る点から観ればX線に依る劣化は明らかである。财湿 性は少ないが電弧等により高温に曝されると表面が炭 化して著しく絶縁が害せられる.フェノールレジンは 低湿度のときX線による少化は無い様に思われるが， これはフェノールレジンに使用された夾雑物の為之解 される。

ユリアONLY 及びュリアは尿素樹脂で, 特性は第 5,6 表及び第 2 図に示す如くである. 即ちユリアはX 線未照射の方が表面漏洩電流が多く，X線照射の方が 逆に漏洩電流か減少している。この現象はユリアの材

\section{第 5 表 ユリア}

\begin{tabular}{|c|c|c|c|}
\hline \multicolumn{2}{|c|}{ エックス線末照射 } & \multicolumn{2}{|c|}{ エックス線照射 } \\
\hline$\%$ & $\begin{array}{c}\text { 漏 電 流 } \\
\mathrm{A}^{2}\end{array}$ & $\begin{array}{c}\text { 滔 洩電 流 } \\
\mu \quad \mathrm{A}\end{array}$ & ${ }^{8}{ }^{\circ} \mathrm{C}$ 度 \\
\hline 41.5 & 0.00098 & 0.0017 & 18 \\
\hline 52 & 0.00176 & 0.0024 & 18.5 \\
\hline 62 & 0.00594 & 0.01015 & 18.5 \\
\hline 74 & 0.0216 & 0.0293 & 18.5 \\
\hline 78.5 & 0.0758 & 0.0566 & 18.8 \\
\hline 82.5 & 0.0667 & 0.0605 & 18.7 \\
\hline 90.5 & 0.263 & 0.243 & 18.5 \\
\hline 97 & 0.84 & 0.64 & 18.5 \\
\hline
\end{tabular}

供給電圧直流 960 ボルト 電極間隔 $4.2 \mathrm{~mm}$ 


\begin{tabular}{|c|c|c|c|}
\hline & 第 6 表 ユ & $\boldsymbol{ア}$ & \\
\hline \multicolumn{2}{|c|}{ エックス線末照射 } & \multicolumn{2}{|c|}{ エックス線照射 } \\
\hline 湿 & $\begin{array}{c}\text { 漏㳦電流 } \\
\mu \quad \mathrm{A}\end{array}$ & $\begin{array}{c}\text { 瀮浅霓流 } \\
\mu \mathrm{A}\end{array}$ & ${ }^{\text {温 }{ }^{\circ} \mathrm{C}}$ \\
\hline 41.5 & 0.00234 & 0.00171 & 18 \\
\hline 53 & 0.00252 & 0.0019 & 18.5 \\
\hline 62 & 0.00306 & 0.00208 & 18.5 \\
\hline 74 & 0.00664 & 0.00313 & 18.5 \\
\hline 79 & 0.0126 & 0.00437 & 18.5 \\
\hline 82.5 & 0.01155 & 0.00512 & 18.7 \\
\hline 92.2 & 0.047 & 0.022 & 18.5 \\
\hline 97 & 0.1483 & 0.1515 & 18.5 \\
\hline
\end{tabular}

供給電厈直流 960 ボルト 電極間隔 $4.0 \mathrm{~mm}$

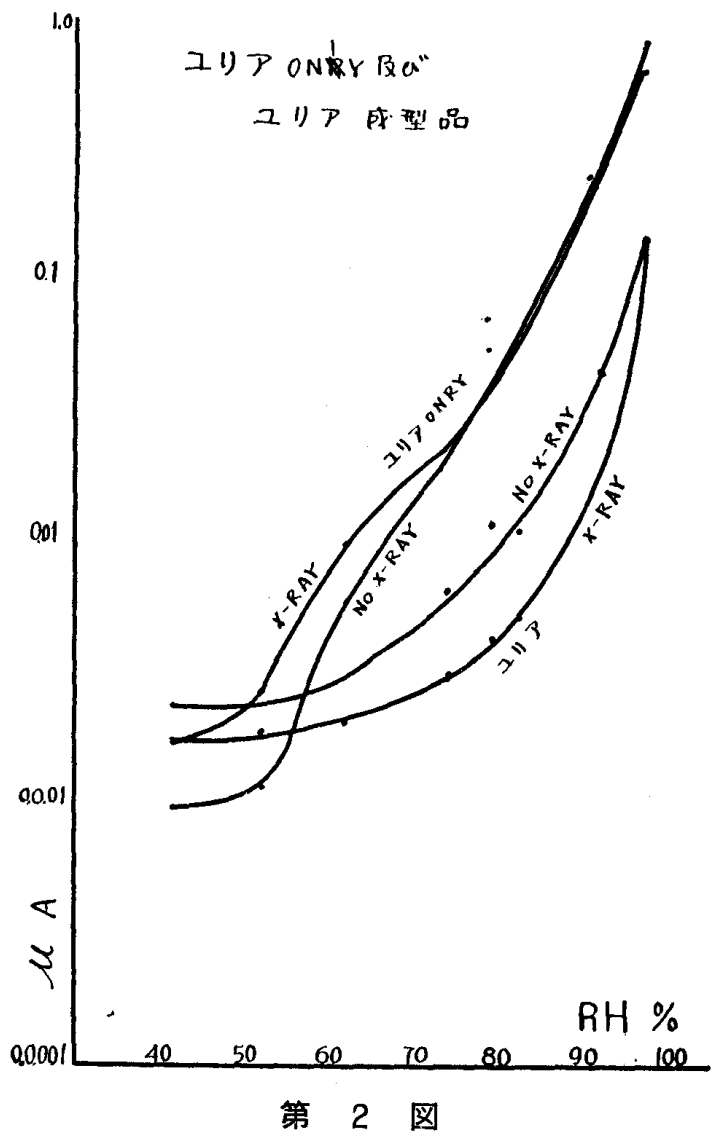

質特性と解される。ユリア ONLY の場合は途中で特 性曲線が交攴しているが，ての理由は不詳である。工 リア及びュリア ONLY は共に财湿性があるが，消西 性瓦斯発発生するため火花等による表面の炭化がない ので, 絶縁の著しく低下する様子恐れは無い。

メラミン.ビニラールの特性は第 7,8 表及び第 3 図 で示す如く両材料共にュリア ONLY と同様に特性曲 線が交双している.メラミンは吸湿性少なく消弧性の 瓦斯を発生する点㽷素樹脂と同様である．ビニラール
第 7 表 $メ$ ミン

\begin{tabular}{|c|c|c|c|}
\hline \multicolumn{2}{|c|}{ エックス線未照射 } & \multicolumn{2}{|c|}{ エックス線照射 } \\
\hline 湿 $\%$ & $\begin{array}{c}\text { 漏洩電 流 } \\
\mu \quad \mathrm{A}\end{array}$ & $\begin{array}{c}\text { 漏洩 電流 } \\
\mu\end{array}$ & ${ }^{\circ}{ }^{\circ} \mathrm{C}^{\text {度 }}$ \\
\hline 42 & 0.182 & 0.252 & 18 \\
\hline 53 & 0.2075 & 0.273 & 18.5 \\
\hline 62 & 0.246 & 0.292 & 18.5 \\
\hline 74 & 0.344 & 0.342 & 18.5 \\
\hline 81 & 0.487 & 0.446 & 18.8 \\
\hline 82.5 & 0.486 & 0.473 & 18.7 \\
\hline 91 & 0.63 & 0.623 & 18.5 \\
\hline 97 & 0.78 & 1.364 & 18.5 \\
\hline
\end{tabular}

供給電生直流 960 ポルト電極間隔 $4.08 \mathrm{~mm}$

第 8 表 ビニラール緑

\begin{tabular}{|c|c|c|c|}
\hline \multicolumn{2}{|c|}{ エックス線末照射 } & \multicolumn{2}{|c|}{ エックス線照射 } \\
\hline 湿 $\%$ & $\begin{array}{c}\text { 满洩 電流 } \\
\mu \quad \mathrm{A}\end{array}$ & $\begin{array}{c}\text { 漏洩電 流 } \\
\mu \mathrm{A}\end{array}$ & ${ }^{{ }^{\circ} \mathrm{C}}{ }^{\text {度 }}$ \\
\hline 43 & 0.0018 & 0.00227 & 18 \\
\hline 52 & 0.00216 & 0.00284 & 18.5 \\
\hline 62 & 0.00387 & 0.0062 & 18.5 \\
\hline 74 & 0.0616 & 0.0416 & 18.5 \\
\hline 78 & 0.204 & 0.0815 & 18.8 \\
\hline 82.5 & 0.522 & 0.159 & 18.7 \\
\hline 91.5 & 0.99 & 0.378 & 18.7 \\
\hline 97 & 1.63 & 0.748 & 18.7 \\
\hline
\end{tabular}

供給電圧直流 860 ボルト 電極間隔 $3.5 \mathrm{~mm}$

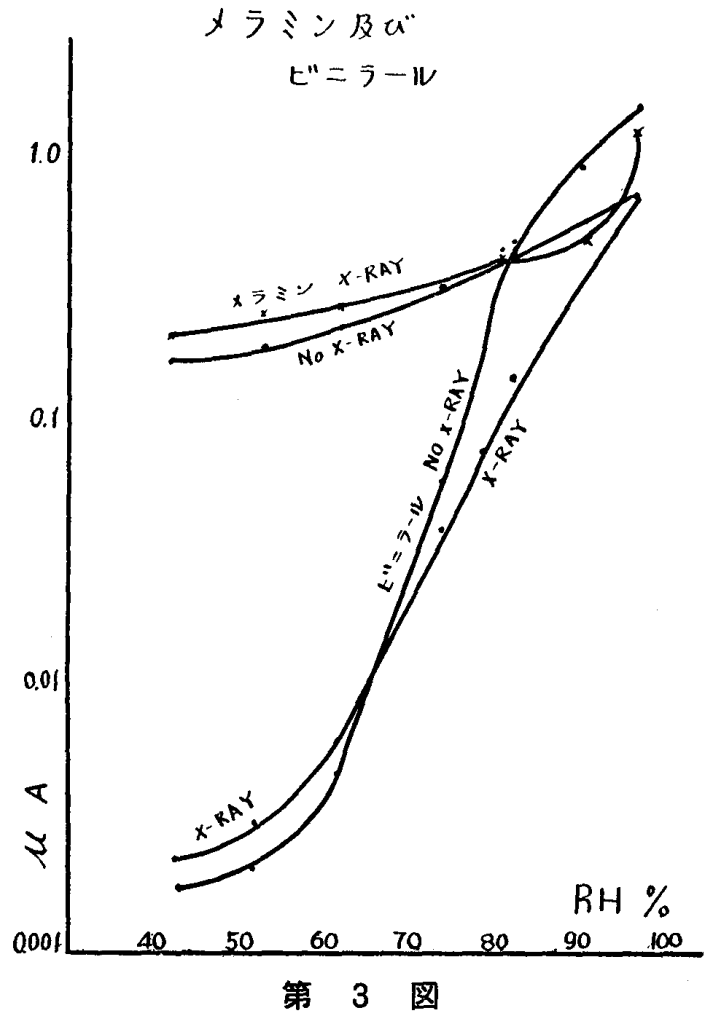


は湿度の変化に対する漏浅電流が大きい為余り使用さ れていない。

エボナイトはゴムの加硫を高度にしたもので, 配合 により，材質も異なるが良好な電気的性質を有してい る。吸湿性は大で日光，特に紫外線を受けると土ボナ イトは表面加酸化変色し $\mathrm{H}_{2} \mathrm{SO}_{4}$ 等の财湿性イオン化 物質を生じて，表面漏洩抵抗が減少する.(R.H 100\% 中で30分間紫外線を照射した数種のエボナイト試験品 の表面漏洩抵抗が著しく低下した実験がある。）本実 験は紫外線による劣化と同じ特性を示すのではないか と考えられたが，X線を照射したものより未照射の方 が表面漏洩電流の少なかった事は，紫外線照射による 実験から考えれば少しく疑義がある所である。（第 9 表及び第 4 図)

第 9 表エボナイト

\begin{tabular}{|c|c|c|c|}
\hline \multicolumn{2}{|c|}{ エックス線末照射 } & \multicolumn{2}{|c|}{ エックス線照射 } \\
\hline 湿 & $\begin{array}{c}\text { 漏洩電 流 } \\
\mu \mathrm{A}\end{array}$ & $\begin{array}{c}\text { 漏洩電流 } \\
\mu \quad \mathrm{A}\end{array}$ & ${ }^{\circ} \mathrm{C}{ }^{\text {湜 }}$ \\
\hline 41.5 & 不 能 & 不 能 & 18 \\
\hline 52 & 0.000114 & 0.00009 & 18.5 \\
\hline 62 & 0.000873 & 0.00081 & 18.5 \\
\hline 74 & 0.114 & 0.0054 & 18.5 \\
\hline 79 & 0.596 & 0.0776 & 18.8 \\
\hline 82.5 & 0.37 & 0.0477 & 18.7 \\
\hline 92 & 1.704 & 0.315 & 18.5 \\
\hline 97 & 2.325 & 0.239 & 18.5 \\
\hline
\end{tabular}

供給電圧直流 960 ボルト 電極間隔 $3.4 \mathrm{~mm}$

\section{結語}

各実験材料の表面膤㑩電流は，大気の湿度の変化に 伴い著しく増減する. 此の理由こして材料の表面に生 じた水の薄膜が主として導電にあずかるものと考えら れている，又表面抵抗は温度の影響を受ける事が少な いと請れている．X線を照射した材料中明らかにベー クライトが劣化しているが，てれは先に本会誌第 9 巻 第 2 号に於て, テコライトカバーの少化に就いで報告 をしたが，本実験でもこれと同様の結果を得た。エボ ナイトでは予期された結果は得られなかったがてれは エボナイト本来のものか，又は表面をベンジンで拭っ

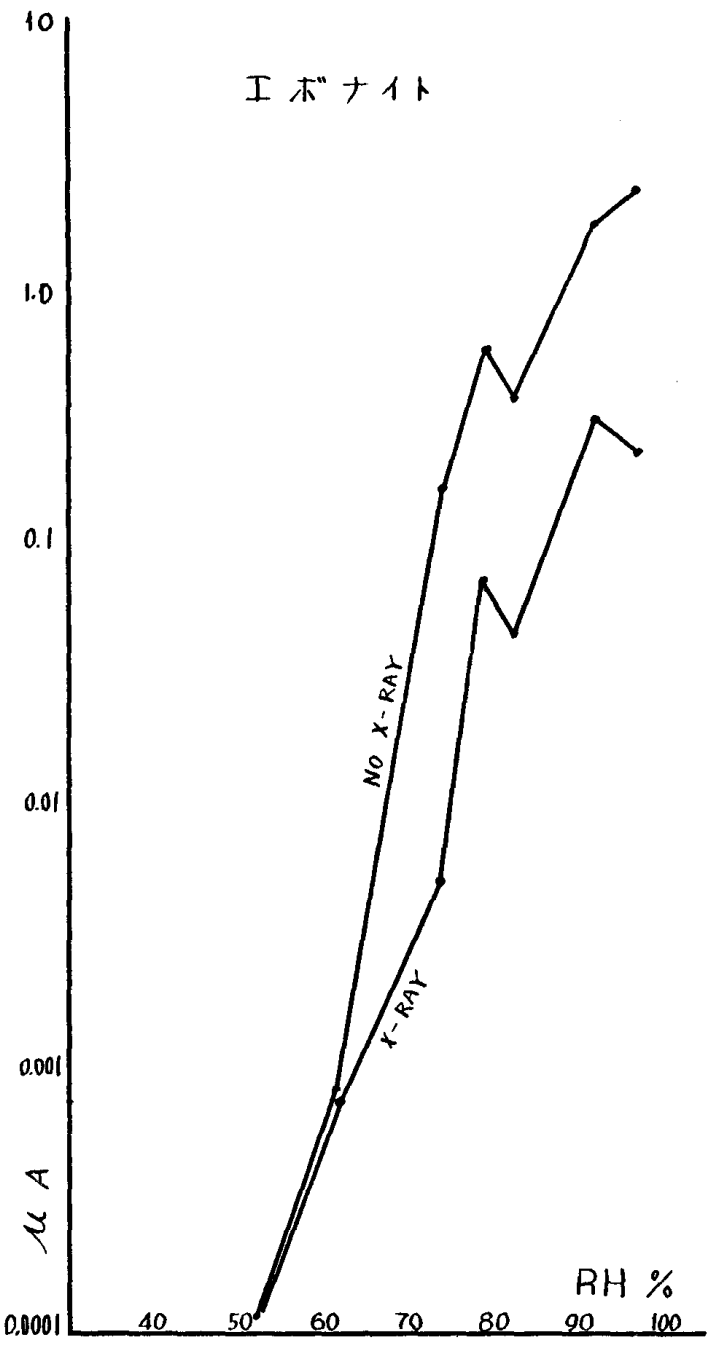

第 4 図

た為表面の電気的諸状態に変化を及ばしたか，或は工 ボナイト自身の忣收電流が関係したのか判然としはい ので,今後此等の点に就き研究をしたいと考えている。

本奏験に際し御多忙中終始御指導を賜わった日本大 学工学部電気科山本滀先生及び御校閲を踢わった医務 課長神野友次先生に衰心より感謝と敬意を表する次第 である・

参考 交 献

喜多：日本放射線技術学会誌第 9 巻第 2 号 電気材料学：共立出版株式会社 